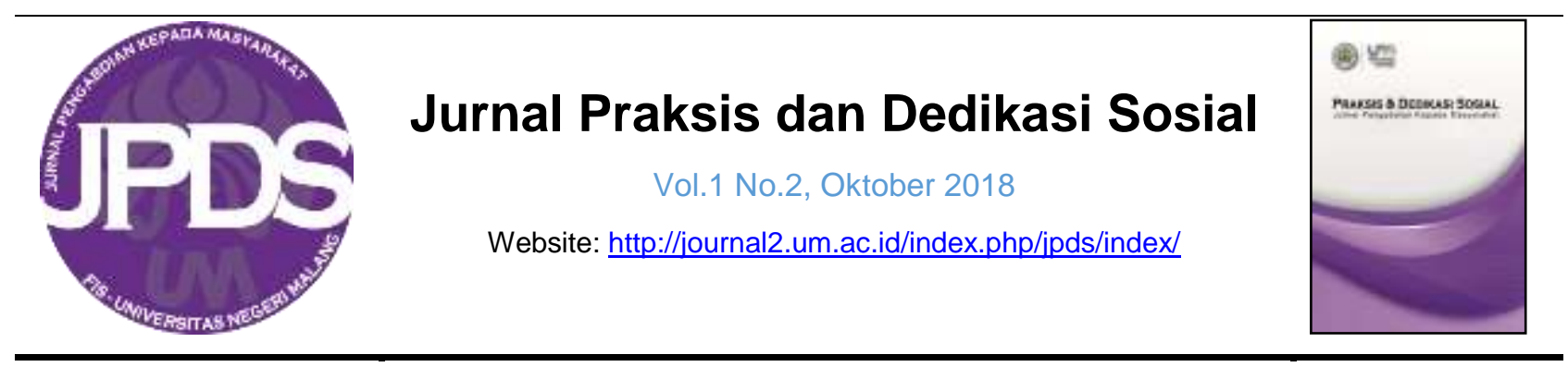

\title{
PENDAMPINGAN PEMETAAN POTENSI PERTANIAN LOKAL DAN PENGELOLAANNYA DALAM MENDUKUNG AGRO EKOWISATA KECAMATAN KANDANGAN KABUPATEN KEDIRI
}

\author{
Sumarmi ${ }^{1}$, Syamsul Bachri ${ }^{2}$, Elya Kurmiawati ${ }^{3}$ \\ ${ }^{1,2,3}$ Jurusan Geografi, Fakultas IImu Sosial, Universitas Negeri Malang. \\ Diterima 1 September 2018, dipublikasikan 31 Oktober 2018.
}

\begin{abstract}
Abstrak
Pengabdian mayarakat ini bertujuan untuk (1) Meningkatkan kesadaran masyarakat dalam mengenali potensi pertanian lokal yang bernilai ekonomis. (2) Meningkatkan kemampuan masyarakat desa, dalam mengolah potensi pertanian lokal sebagai pendukung agro ekowisata. Kegiatan pengabdian masyarakat ini dilakukan melalui pendampingan kepada masyarakat, terutama pada ibu-ibu PKK. Mata pencaharian masyarakat saat yang ini di sektor pertanian. Dari hasil pengabdian masyarakat ini teridentifikasi potensi pertanian lokal yang mempunyai nilai ekonomis tinggi untuk mendukung ekowisata yaitu: durian, cengkeh, kopi, salak, manggis, pisang, jamur tiram, susu sapi perah. Melalui kegiatan ini ibu-ibu PKK dilatih tidak hanya bergantung pada pertanian saja namun juga ditopang ekonomi kreatif dari pengolahan hasil pertanian untuk oleh-oleh wisata. Sehingga tingkat kesejahteraan masyarakat lebih meningkat. Karena potensi pertanian lokal yang selama ini nilai jualnya rendah bisa meningkat dengan cara melakukan pengolahan dan pemasaran sebagai oleh-oleh wisata.
\end{abstract}

\section{Kata Kunci}

Potensi Pertanian Lokal, Pengelolaan, Agro Ekowisata

(C) 2018 Penulis

\section{PENDAHULUAN}

Kediri merupakan daerah dengan kekayaan alam dan budaya yang dapat dimaksimalkan melalui kegiatan pariwisata. Kegiatan industri pariwisata merupakan salah satu kegiatan yang dapat mempercepat peningkatan ekonomi daerah melalui optimalisasi penyerapan penerimaan pendapatan asli daerah. Hal tersebut dikarenakan sektor pariwisata memiliki peran

\footnotetext{
${ }^{1}$ Surel Korespondensi: sumarmi.fis@um.ac.id
}

yang sangat penting disamping sektor migas untuk menggerakkan sektor ekonomi dan sektor-sektor lainnya, bahkan diharapkan dapat menjadi penghasil devisa Negara (Suwantoro, 1997).

Kegiatan industri pariwisata mempunyai konsekuensi logis yang dapat mempengaruhi sektor-sektor lain yang saling berkaitan seperti ekonomi, ekologi, politik, sosial, dan budaya, serta interaksi antar wilayah, baik pengaruh secara langsung 


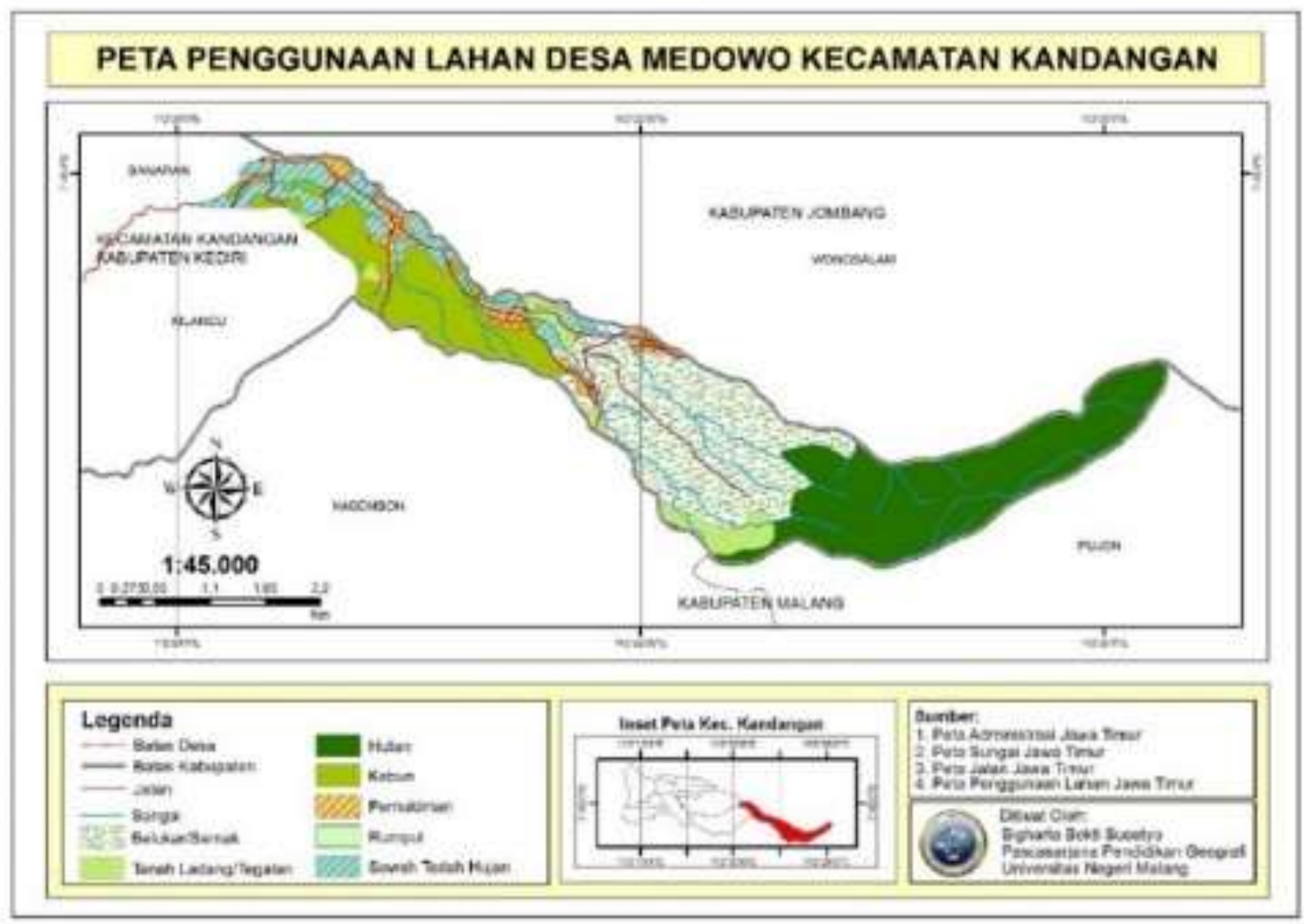

Gambar 1. Peta Penggunaan Lahan Desa Medowo Kecamatan Kandangan

maupun tidak langsung. Salah satu wisata alam yang digunakan untuk menggerakkan pengembangan desa sebagai desa wisata di Kabupaten Kediri adalah Wisata Bukit Gangrung yang ada di Desa Medowo.

Kabupaten Kediri dan eksotisme pariwisatanya memang tak bisa dipisahkan. Pariwisata terus tumbuh menjadi sektor andalan yang menunjang perekonomian Kabupaten Kediri. Pemerintah Kabupaten Kediri memang memberikan perhatian khusus untuk bidang pariwisata. Beragam program terobosan terus dilakukan untuk meningkatkan kualitas dan kunjungan dari para wisatawan.

Selain perbaikan dan peningkatan kualitas di obyek wisata, juga diupayakan pengembangan beberapa kawasan penyangga wisata. Sehingga optimalisasi pariwisata bisa juga dirasakan warga sekitar yang pada akhirnya akan meningkatkan kesejahteraan. Salah satunya adalah dengan mengembangkan Desa Wisata. Dalam konsep Edward Inskeep dalam Tourism Planning An Integrated and Sustainable Development Approach, hal. 166 memberikan definisi Desa Wisata yakni wisata pedesaan dimana sekelompok kecil wisatawan tinggal dalam atau dekat dengan suasana tradisional, sering di desa-desa yang terpencil dan belajar tentang kehidupan pedesaan dan lingkungan setempat.

Strategi dan terobosan Desa Wisata menitikberatkan interaksi antara penduduk 
dan wisatawan serta eksplorasi mendalam terhadap potensi yang ada di desa tersebut. Potensi yang 'dijual' dapat berupa budaya, alam, sejarah ataupun aktivitas sehari-hari warga desa. Banyak desa di Kabupaten Kediri yang berpotensi menjadi Desa Wisata. Diantaranya adalah Desa Medowo di Kecamatan Kandangan. Desa ini terletak di ujung Timur Laut Kabupaten Kediri. Tepatnya di lereng Gunung Anjasmara (https://kedirikab.go.id/index.php?). Desa yang berada di ujung timur Kabupaten Kediri ini memang menyimpan banyak potensi. Letaknya yang berada di ketinggian lebih 700 mdpal memberikan beberapa spot wisata yang memiliki pemandangan luar biasa. Salah satunya adalah Bukit Gandrung Tanggulasi. Bukit ini memang istimewa. Saat berada di puncak bukit, maka dengan mudah bisa melihat Gunung Kelud, Jombang, Kasembon-Malang dan banyak tempat indah lainnya. Karena titik yang strategis ini pula, membuat bukit Gandrung sudah menjadi titik pemantauan pasukan Belanda pada zaman penjajahan dulu.

Yang sangat berpotensi untuk dapat dikembangkan menjadi objek ekowisata. Adanya pengembangan kawasan wisata Bukit Gangrung, maka akan dapat meningkatkan daya tarik wisatawan. Wisatawan dapat melakukan berbagai kegiatan wisata seperti berjalan menuju Bukit Gangrung melalui jogging track maupun menggunakan menggunakan sepeda motor untuk menuju Sumber Jodo, serta melihat keanekaragaman flora dan faunanya. Wisatawan akan mendapatkan edukasi mengenai keanekaragaman jenis tanaman yang ada di sekitar Sumber Jodo, dan manfaat Air Terjun.

Dalam kegiatan pengabdian masyarakat ini, permasalahan yang dirumuskan yang perlu dipecahkan adalah: (1) Rendahnya kesadaran masyarakat dalam mengenali potensi pertanian lokal yang bernilai ekonomis. (2) Rendahnya kemampuan masyarakat desa, dalam mengolah potensi pertanian lokal sebagai pendukung pariwisata. (3) Kurangnya kemampuan masyarakat dalam merencanakan bisnis dalam pengelolaan agro ekowisata.

Pengabdian masyarakat ini bermanfaat bagi masyarakat, khususnya masyarakat di Desa Wisata Medowo, Kecamatan Kandangan Kabupaten Kediri. Hasil pengabdian masyarakat ini juga dapat digunakan sebagai referensi atau rujukan bagi masyarakat yang ingin melakukan pengelolaan agro ekowisata. Selain itu, dapat dijadikan literatur pembaca, saran untuk pengembangan dan pemberdayaan masyarakat yang ada di Desa wisata Medowo, Kecamatan Kandangan, Kabupaten Kediri. Selain itu juga bermanfaat bagi Pemerintah Pusat, Pemerintah Provinsi, serta Pemerintah Daerah Kabupaten Kediri terutama Dinas Kebudayaan dan Pariwisata dalam merumuskan dan mengambil kebijakan dalam pengembangan pariwisata, serta mendukung pengembangan Agro Ekowisata. 


\section{METODE}

Untuk merealisasikan pemecahan masalah dalam pengabdian masyarakat ini dilakukan tiga tahapan sebagai berikut: 1) Tahap persiapan; 2) Tahap pelaksanaan; 3) Tahap tindak lanjut.

\section{Tahap Persiapan}

Desa Medowo terdiri dari 4 Dusun yaitu Dusun Sidomulyo, Medowo, Sidorejo dan Dusun Ringinagung. Pada tahap ini diidentifikasi masyarakat yang mempunyai minat dalam pengolahan sumber daya pertanian lokal untuk mendukung pengembangan agro ekowisata.Kegiatan persiapan secara substansial dilakukan untuk menyusun secara operasional kegiatan pengabdian masyarakat yang meliputi: 1) Penyusunan jadwal pendampingan; 2) Penentuan peserta pendampingan; 3) Mempersiapkan bahanbahan dan tempat pendampingan.

\section{Tahap Pelaksanaan}

Agar kegiatan pengabdian masyarakat ini berjalan dengan baik, maka jadwal yang sudah disusun diikuti dengan baik. Selain itu perlu ada mahasiswa yang dilibatkan dalam kegiatan pendampingan pengabdian ini, baik membantu dalam proses pendampingan maupun dalam melakukan identifikasi potensi pertanian local, untuk lebih memperdalam ilmu mahasiswa. Pelaksanaan kegiatan pengabdian masyarakat ini juga akan melibatkan Pamong Desa Medowo. Pelibatan pamong desa ini untuk mempermudah proses mengidentifikasi peserta, dan identifikasi usaha-usaha apa saja yang selama ini bisnis sudah dan yang belum dimiliki masyarakat. Sehingga pendampingan bisa memperkaya ketrampilan masyarakat dalam mengelola usaha yang berorientasi pada sektor pertanian dibawa sampai pada proses pengolahan pasca panen untuk mendukung pengembangan agro ekowisata.

$$
\text { Untuk pelaksanaan kegiatan }
$$
pengabdian masyarakat ini dijabarkan dalam tahapan-tahapan sebagai berikut: 1) Melatih ibu-ibu PKK mengenali potensi sumber daya pertanian lokal yang mempunyai nilai ekonomis; 2) Melatih ibu-ibu PKK mengolah potensi sumber daya pertanian lokal untuk menjadi produk oleh-oleh wisata; 3) Melatih ibu-ibu PKK dalam mengemas produk olahan yang berasal dari potensi pertanian lokal; 4) Melatih ibu-ibu PKK dalam memasarkan produk olahan yang berasal dari potensi pertanian lokal; 5) Mendampingi masyarakat dalam memetakan potensi pertanian lokal yang mendukung agro ekowisata; 6) Mendampingi masyarakat dalam merencanakan bisnis dalam pengelolaan agro ekowisata.

\section{Tahap Tindak Lanjut}

Rencana tindak lanjut yang dilakukan dalam pengabdian ini yaitu: Setelah melakukan pendampingan identifikasi potensi pertanian lokal dan pengelolaanya, peserta kegiatan pengabdian masyarakat ini diharapkan mampu membuat produk-produk hasil olahan hasil pertanian yang mempunyai nilai ekonomis tinggi dan mengelola bisnis agro ekowisata. 
HASIL DAN PEMBAHASAN

\section{Memetakan Potensi Pertanian Lokal}

Desa Medowo mempunyai luas wilayah $997 \mathrm{Ha}$, sebelah utara berbatasan dengan Desa Galengdowo Kecamatan Wonosalam Kabupaten Jombang, sebelah selatan berbatasan dengan Hutan Negara/KKPH Malang. Sedangkan sebelah timur berbatasan dengan Hutan Negara/Taman Hutan Raya (TAHURA) Propinsi Jawa Timur dan sebelah barat berbatasan dengan Desa Banaran dan Desa Mlancu Kecamatan Kandangan. Desa Medowo terdiri dari 4 Dusun yaitu Dusun Sidomulyo, Medowo, Sidorejo dan Dusun Ringinagung. Untuk menuju lokasi Desa Medowo dapat ditempuh melalui Pasar Kandangan menuju arah Timur sekitar $8 \mathrm{Km}$. Mata pencaharian masyarakat disini pada umumnya adalah pada sektor pertanian. Roda perekonomian masyarakat desa Medowo nantinya diharapkan tidak hanya bergantung pada pertanian saja namun juga ditopang ekonomi kreatif dari sektor agro ekowisata.

Seperti di pedesaan pada umumnya, penggunaan lahan di Desa Medowo antara lain untuk tanah ladang/tegalan, hutan, kebun, permukiman, sawah irigasi dan sawah tadah hujan. Dari kondisi penggunaan lahan tersebut maka Desa Medowo mempunyai potensi lokal yang layak dikembangkan sebagai agro wisata sebagai berikut: Pada lahan hutan mempunyai potensi yang sangat indah sebagai tempat wisata, antara lain Air Terjun
Tretes, Air Terjun Sumber Jodo, wisata Tanggulasi di Bukit Gangrung. Wisata Tanggulasi ini merupakan salah satu Situs Belanda. Tempat ini merupakan tempat yang paling tinggi dibanding wilayah sekitarnya. Karena posisinya yang seperti itu dulunya digunakan oleh Belanda sebagai tempat pengamatan musuh. Lokasi tempat wisata Tanggulasi di Bukit Gandrung seperti nampak pada Gambar 2.

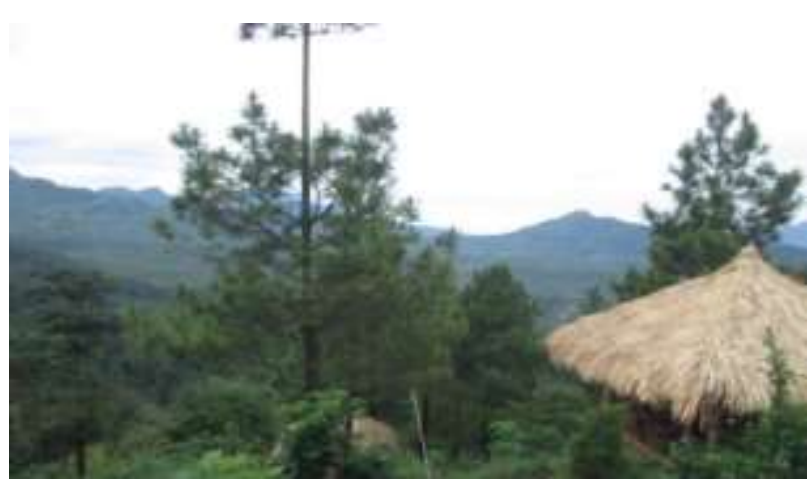

Gambar 2. Pemandangan dari atas Bukit Gandrung

\section{Mengenali potensi sumber daya pertanian lokal yang mempunyai nilai ekonomis}

Sumberdaya pertanian lokal yang mempunyai nilai ekonomis tinggi yang ada di desa Medowo yang bias mendukung agro ekowisata antara lain tanaman tanaman durian, kopi, cengkih, pisang, manggis, salak, ubi, labu kuning, jamur tiram. Di sektor budidaya peternakan yang menjadi andalan adalah sapi perah. Beberapa contoh potensi pertanian lokal dapat dilihat pada Gambar 3, Gambar 5, Gambar 5. Gambar 6 dan Gambar 7. 


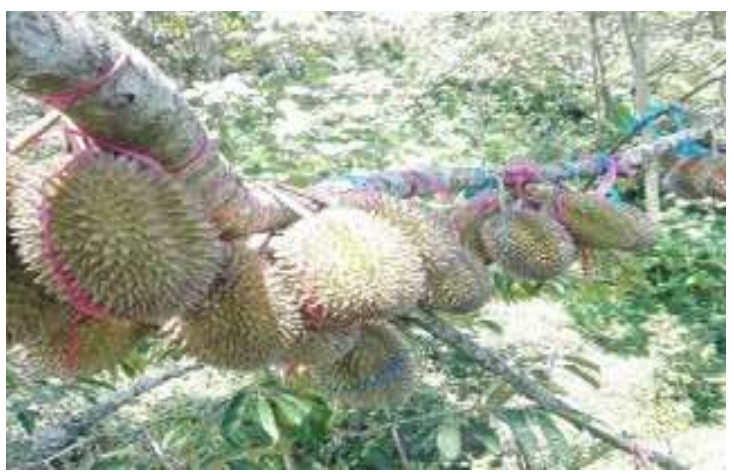

Gambar 3. Durian yang banyak ditanam di Tegalan

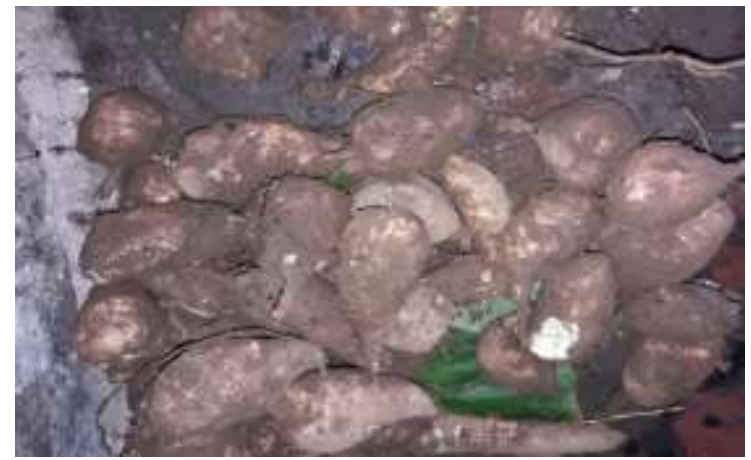

Gambar 5. Ubi Jalar

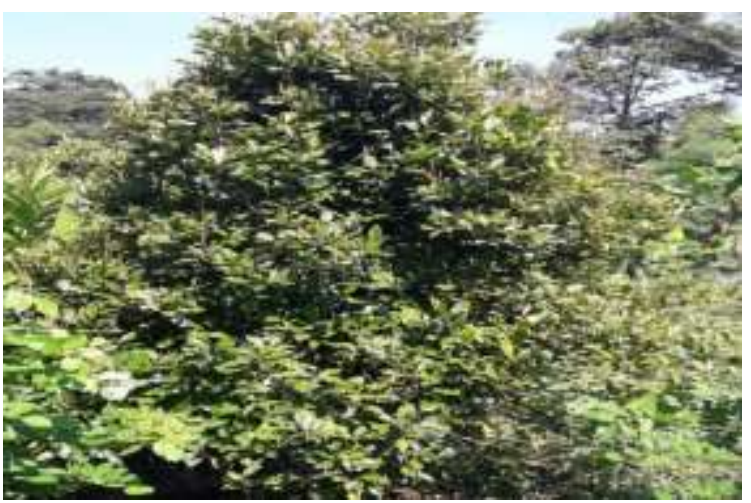

Gambar 7. Pohon Cengkeh

\section{Mengolah potensi daya pertanian lokal untuk menjadi oleh-oleh wisata}

Bagi wisatawan yang berkunjung di Desa Wisata Medowo, bisa didapatkan oleholeh wisata baik berupa buah-buahan langsung misalnya durian, manggis, salak, pisang, maupun dari hasil pertanian yang sudah diolah dengan berbagai macam olahan yang sudah diajarkan dalam kegiatan pengabdian masyarakat ini. Contoh

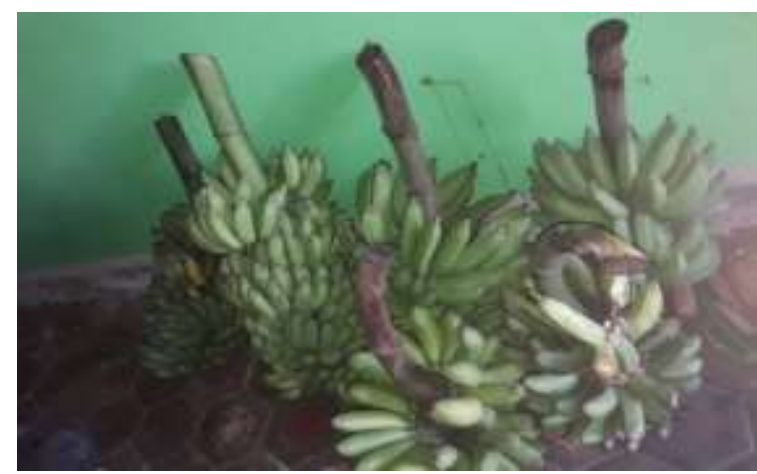

Gambar 4. Pisang Raja yang baru dipanen Sumber: Data Peneliti 2018

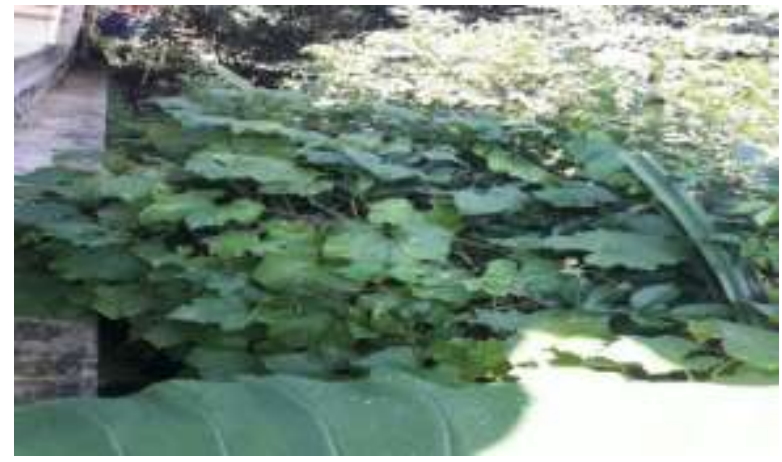

Gambar 6. Tanaman Labu

Sumber: Data Peneliti 2018

jenis olahan, bahan, dan cara penglohannya yang sudah diajarkan dalam pengabdian masyarakat ini antara lain donat beku, eskrim ubi, wedang uwuh, dan abon bonggol pisang.

\section{Donat Beku}

Bahan-bahan: ragi instan, gula pasir, susu bubuk, baking powder, labu kukus, haluskan, telur, air es, margarin, garam, tepung terigu dan gula halus untuk taburan. Cara membuatnya donat beku ini yakni: 1) Langkah pertama campur tepung terigu, ragi instan, gula pasir, susu bubuk, dan baking powder. Aduk hingga merata, tambahkan labu kukus; 2) Langkah kedua tambahkan telur dan air es sedikit demi sedikit sambil diuleni hingga adonan kalis; 3) Langkah ketiga masukkan margarin dan garam. Uleni sampai elastis dan diamkan 15 selama 


\section{Sumarmi dkk.}
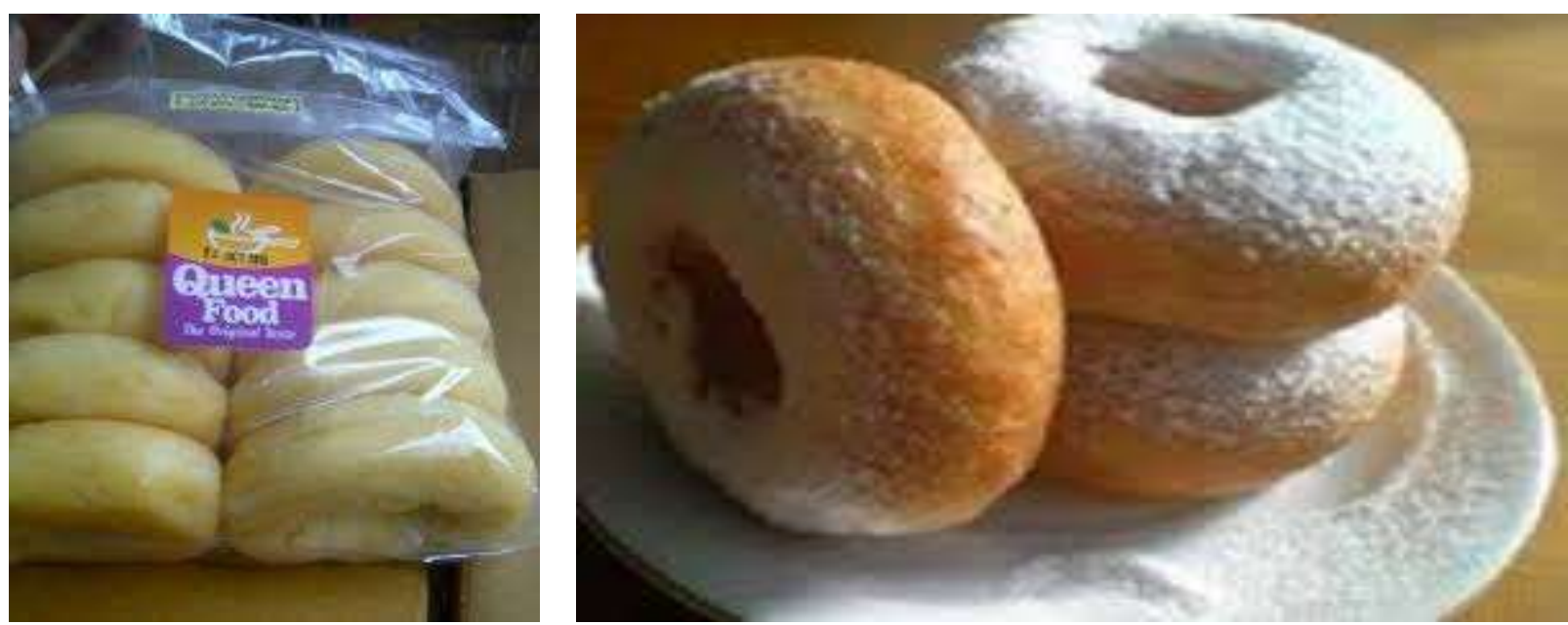

Gambar 8. Olahan donat dari labu kuning

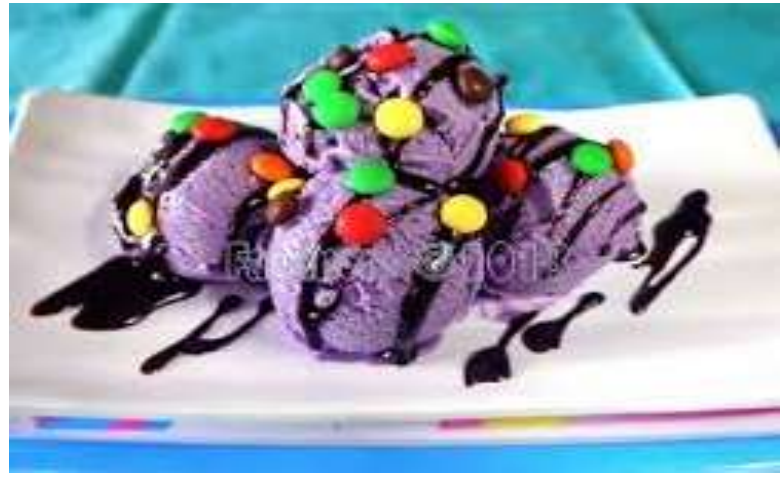

Gambar 9. Olahan Es Krim dari Ubi Ungu

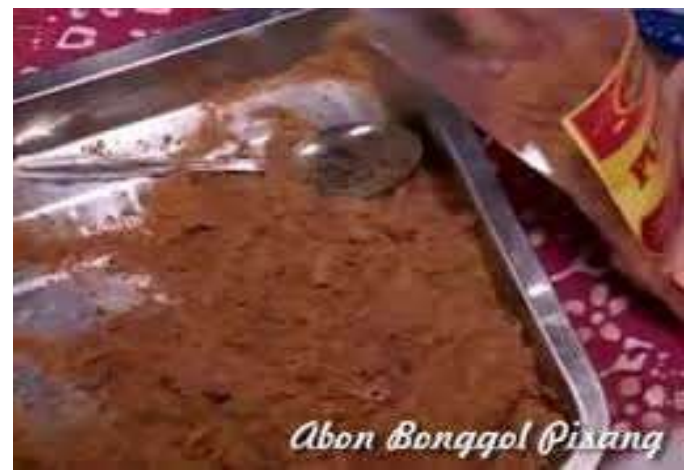

Gambar 11. Abon bonggol pisang dan proses pembuatannya

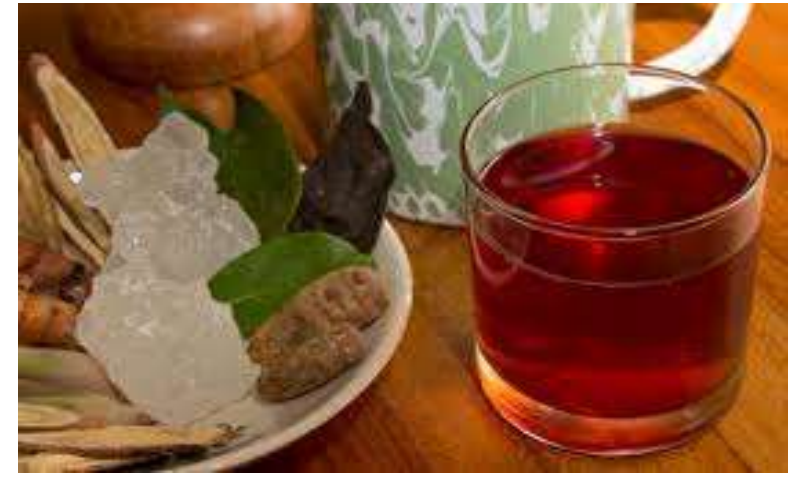

Gambar 10. Wedang Uwuh

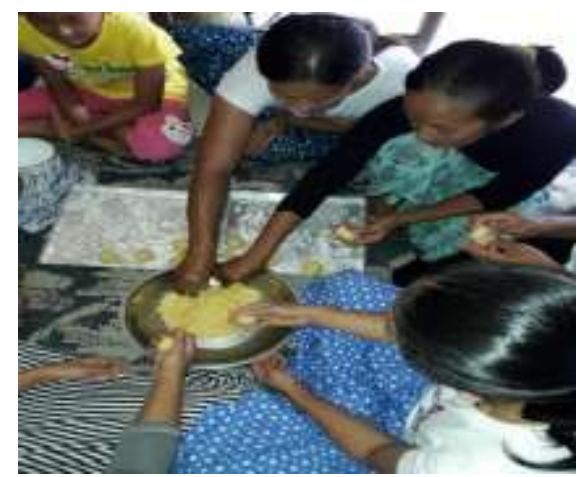

menit; 4) Langkah keempat kempiskan adonan. Timbang masing-masing $40 \mathrm{gr}$. Bulatkan. Diamkan selama 10 menit. Pipihkan adonan lalu lubangi tengahnya. Diamkan selama 35 menit sampai menggembang di atas loyang yang ditaburi tepung; dan 5) Langkah kelima goreng dalam minyak panas dengan api kecil, angkat adonan sebelum berubah warna. Setelah dingin masukkan frezzer. Donat hasil olahan dari labu kuning dapat dilihat pada Gambar 8. 


\section{Es Krim Ubi}

Bahan-bahan: ubi kukus, haluskan, gula pasir, santan/susu cair, vanili bubuk, garam halus Cara Pembuatannya adalah: 1) Langkah pertama rebus santan dan gula sambil terus diaduk agar santan tidak pecah; 2) Langkah kedua tambahkan vanili bubuk dan garam, aduk rata; 3) Langkah ketiga setelah rebusan mendidih, matikan api. dinginkan sejenak: 4) Langkah keempat tuang rebusan tersebut kedalam ubi yang telah dihaluskan; 5) Langkah kelima kocok adonan hingga benar-benar halus dan tercampur sempurna; 6) langkah keenam tuang ke dalam wadah. Simpan di frezzer hingga membeku. Jika sudah beku es krim ubi siap disajikan dengan topping yang menarik. Es krim hasil olahan dari ubi dapat dilihat pada Gambar 9.

\section{Wedang Uwuh}

Bahan-bahan: buah cengkeh, batang cengkeh secukupnya, Jahe, kayu secang, Gula pasir/batu, kayu manis, daun kayu manis kering daun pala, serai. Cara membuatnya adalah mula-mula rebus air dalam sebuah panci bersama dengan semua bahan. Rebus hingga mendidih kurang lebih selama 15-20 menit. Setelah rebusan tadi mendidih, angkat lalu saring rebusan air tersebut dengan menggunakan saringan teh agar sisa dari bahan rempah tadi tidak ikut masuk kedalam cangkir. Terakhir sajikan wedang uwuh selagi hangat.

\section{Abon Bonggol Pisang}

Bahan-bahan: bonggol pisang (pilih bonggol pisang yang sudah pernah berbuah), bawang merah, bawang putih, lengkuas batang serai, ketumbar (dihaluskan/diblender), daun salam, daun jeruk purut. Cara Membuatnya adalah: 1) Langkah pertama siapkan bonggol pisang, cuci bersih lalu potong menjadi beberapa bagian yang lebih kecil; 2) Langkah kedua kukus bonggol pisang selama kurang lebih 30 menit. Setelah bonggol pisang berubah warna menjadi kekuningan, angkat kemudian tumbuk sampai lembut; 3) Langkah ketiga siapkan bumbunya. Tumbuk bawang merah, bawang putih, lengkuas dan serai. Setelah hancur, tambahkan ketumbar halus, daun salam, dan daun jeruk purut, tumbuk lagi beberapa saat; Langkah keempat campurkan bumbu ke dalam bonggol pisang yang sudah diaduk tadi sampai tercampur rata; 5) Langkah kelima siapkan wajan, kemudian sangrai adonan sampai matang yang ditandai dengan berubahnya warna menjadi kecokelatan. Angkat abon yang sudah jadi dari wajan; 6) Langkah keenam masukkan ke dalam mesin spinner selama 10 menit untuk mengurangi kadar minyaknya. Selanjutnya abon dari bonggol pisang sudah dapat dikonsumsi dan dikemas untuk disimpan atau dijual. Abon hasil olahan dari bobggol pisang dapat dilihat pada Gambar 11.

\section{Merencanakan bisnis dalam pengelolaan agro ekowisata}

Untuk merencanakan bisnis dalam pengelolaan agro ekowisata setelah hasil 
pertanian lokal yang mempunyai nilai ekonomis tinggi yang sudah dikenali baik yang dijual langsung maupun yang diolah, maka perlu dilakukan pengemasan dan pemasaran.

\section{Mengemas produk olahan yang berasal dari hasil pertanian lokal}

Pada waktu pelatihan peserta dilatih untuk mengemas hasil olahan yang telah dipraktekkan dengan kemasan plastik. Setelah dikemas di plastik kemudian divacum supaya olahan tersebut tahan lama. Untuk olahan yang sifatnya kering maka cara penyimpanannya ditaruh di tempat yang kering supaya tahan lama. Sedangkan olahan yang basah selain dikemas dalam plastik dan divacum kemudian dimasukkan freezer bisa bertahan sampai 6 bulan. Untuk buah-buahan yang dijual langsung perlu dibersihkan dan ditata yang baik.

\section{Memasarkan produk olahan yang berasal}

\section{dari hasil pertanian lokal}

Pemasaran produk olahan ini sudah bisa di pasarkan dengan memanfaatkan gazebo yang ada di area wisata Tanggulasi di Bukit Gandrung. Atau bisa dipasarkan di warung-warung kuliner yang sekarang sudah didirikan di sekitar gapura pintu masuk dekat hutan jati di pertigaan kea rah Kecamatan Wonosalam. Saat ini Pemerintah desa Medowo sedang membangun Ruko yang nantinya sebagai sentra oleh-oleh untuk para wisatawan yang berkunjung ke Desa Wisata Medowo. Di Desa Wisata Medowo ini selain ada Wisata Tanggulasi di Bukit Gandrung, juga ada wisata Gua Landak,
Situs Belanda,dan Air Terjun Sumber Jodo, Air Terjun Tretes. Sehingga hasil olahan dari kegiatan pelatihan ini akan mudah dipasarkan.

\section{KESIMPULAN}

Kegiatan pengabdian masyarakat ini dapat dikatakan berhasil dan sangat bermanfaat bagi masyarakat, terutama untuk ibu-ibu PKK. Mata pencaharian masyarakat saat yang ini di sektor pertanian, dengan menjual hasil-hasil pertanian yang mentah. Hal tersebut menyebabkan nialai jualnya rendah. Dengan pengabdian masyarakat ini diharapkan masyarakat tidak hanya bergantung pada pertanian saja namun juga ditopang ekonomi kreatif dari pengolahan potensi pertanian lokal untuk oleh-oleh pariwisata dalam mendukung agro ekowisata.

\section{DAFTAR PUSTAKA}

Damanik, Janianton dan Helmut E. Weber. 2006. Perencanaan Ekowisata, dari Teori ke Aplikasi. Pusat Studi Pariwisata (PUSPAR) UGM. Yogyakarta: Andi.

Hubeis, A. V. S. (2010). Pemberdayaan perempuan dar masa ke masa. Bogor: IPB Press.

Priyanto, S.H. (2009). Mengembangkan pendidikan kewirausahaan di masyarakat. Jurnal PNFI Volume I No. 1, November 2009, 57-82.

Saugi, Wildan, Sumarno. 2015. Pemberdayaan perempuan Melalui pelatihan pengolahan bahan pangan lokal. Jurnal pendidikan dan pemberdayaan masyarakat volume 2 , nomor 2, november 2015, (226 - 238).

Suwantoro, Gamal. 1997. Dasar-dasar Pariwisata. Yogyakarta: Andi

Undang-Undang Republik Indonesia Nomor 10 Tahun 2009 tentang 
Pendampingan pemetaan Potensi Pertanian Lokal dan Pengelolaannya...

Penyelenggaraan Kepariwisataan Indonesia.
Yoeti, Oka. A. 2000. Ekowisata: Pariwisata berwawasan Lingkungan Hidup. Jakarta: PT Pertja.

(https://kedirikab.go.id/index.php?) 